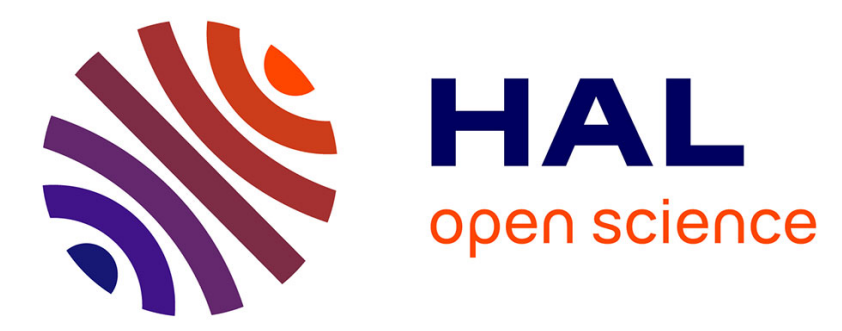

\title{
Effects of dietary coconut oil on blood transport and in vivo hepatic metabolism of fatty acids in the preruminant calf
}

Dominique Bauchart, Denys Durand, C. Picherit, Benoit Graulet, Dominique Gruffat

\section{To cite this version:}

Dominique Bauchart, Denys Durand, C. Picherit, Benoit Graulet, Dominique Gruffat. Effects of dietary coconut oil on blood transport and in vivo hepatic metabolism of fatty acids in the preruminant calf. Reproduction Nutrition Development, 1998, 38 (2), pp.203-204. hal-00900180

\section{HAL Id: hal-00900180 https://hal.science/hal-00900180}

Submitted on 1 Jan 1998

HAL is a multi-disciplinary open access archive for the deposit and dissemination of scientific research documents, whether they are published or not. The documents may come from teaching and research institutions in France or abroad, or from public or private research centers.
L'archive ouverte pluridisciplinaire HAL, est destinée au dépôt et à la diffusion de documents scientifiques de niveau recherche, publiés ou non, émanant des établissements d'enseignement et de recherche français ou étrangers, des laboratoires publics ou privés. 
Energy restriction had no effect on the liver fatty acid profile. In contrast, high-fat energy restricted diets (groups C and D) induced important modifications to the profile. By comparing groups $\mathrm{C}$ and $\mathrm{D}$ with group $\mathrm{A}$, the following results were found: $14: 0-38.5 \%$ and $+55.2 \% ; 16: 0$ $-8.7 \%$ and $+13.7 \% ; 16: 1-47.4 \%$ and $-29.5 \% ; 18: 0+32.1 \%$ and $+26.9 \% ; 18: 1$ $+0.2 \%$ and $-13.2 \% ; 18: 2+55.8 \%$ and $+44.1 \% ; 20: 4+41.2 \%$ and $+25.9 \%$. It was interesting that the two lipid sources produced different changes.

It can be concluded that energy restriction was unable to modify the liver fatty acid profile in obese Zucker rats. In contrast, dietary lipids were a factor that could induce important modifications in this profile, depending on the nature of the fatty acids.

\section{Modulation of the triglyceride-rich} lipoprotein (trl) hepatic uptake by high satured or unsaturated fatty acids in the nzw rabbit. C. Juhel, A. Harbis, Y. Pafumi, D. Lairon (Inserm U 130, 18, avenue Mozart, 13009 Marseille, France).

A decreasing level of TRL clearance during the postprandial state allows the formation of atherogenic remnants and in the long term can lead to development of cardiovascular diseases. We studied one of the factors implicated in TRL clearance: the hepatic uptake by lipoprotein receptors. Rabbits $(n=36)$ were fed a cholesterol free, low fat $(2.7 \%)$ diet $(\mathrm{T})$, or hypercholesterolemic diets containing $0.35 \%$ cholesterol and $10 \%$ fat which were either saturated (lard, L) or monounsaturated (olive oil, OOC) or polyunsaturated (sunflowers oil, SO) fatty acids, or cholesterol free but $10 \%$ fat diets represented by either SFA (coconut oil, $\mathrm{CO}$ ) or MUFA (olive oil, OO). The overall study lasted $28 \mathrm{~d}$. We compared the uptake of TRL from L, OOC and SO rabbits by studying cultured liver cells freshly iso- lated from T, L, OOC and SO rabbits. We measured the lipoprotein binding to LDL receptor (LDL-R) and lipolysis stimulated receptor (LSR) using hepatocyte plasmic membranes isolated from $\mathrm{T}, \mathrm{CO}$ and $\mathrm{OO}$ rabbits.

The hepatocyte culture experiments showed i) that the TRL disappearance was delayed in hypercholesterolemic rabbits as compared to $T$ ones, ii) whatever the hepatocyte, uptake of TRL isolated from OOC and SO rabbits was faster than those of Ls. As compared to T rabbits, intracellular free cholesterol concentrations were two fold higher in rabbits on the atherogenic diet for $28 \mathrm{~d}$. The SFA (CO) diet increased lipoprotein binding to LDL-R while it decreased with the MUFA (OO) diet. A comparable figure was noted for LSR after $14 \mathrm{~d}$ on fat rich diet.

In conclusion, the reduced LDL-R and LSR binding activity could explain the delayed clearance of TRL observed in hypercholesterolemic L rabbits, as compared to those on UFA diet. These data could be related to the hypercholesterolemic effect of SFA and to the protective effect of MUFA or PUFA on atherosclerosis in humans.

Effects of dietary coconut oil on blood transport and in vivo hepatic metabolism of fatty acids in the preruminant calf. D. Bauchart, D.Durand, C. Picherit, B. Graulet, D. Gruffat (Inra, LCMH, Theix, 63122 St-Genès-Champanelle, France).

The strict incorporation of triglycerides (TG) from plant origin in milk replacers for calves has become necessary to avoid any risks of bovine spongiform encephalopathy transmission. Coconut oil, rich in medium-chain fatty acids, stimulates the growth of the young calf by favouring muscle protein accretion, but its effects on the lipid metabolism have 
yet to be clarified. Two groups of six Friesian $\times$ Holstein male calves, aged $15 \mathrm{~d}$, were given a conventional milk replacer containing $22.4 \%$ dry matter as beef tallow $(\mathrm{T})$ or coconut oil (CO) for $19 \mathrm{~d}$. At the end of the experiment, $500 \mathrm{~mL}$ of peripheral blood and $10 \mathrm{~g}$ of liver tissue were sampled under total anesthesia. Plasma lipoproteins were separated by sequential ultracentrifugal flotation. The major lipid classes of lipoproteins and of the liver were analysed by enzymatic methods. They were separated by thinlayer chromatography and their fatty acids were analysed by gas-liquid chromatography. Hepatic concentrations of apoproteins (apo) A-I and B 100, and of albumin were evaluated by western blot analysis using rabbit antisera to bovine apo A-I, apo B 100 and albumin. Compared with the $\mathrm{T}$ diet, the $\mathrm{CO}$ diet induced a TG infiltration in the liver ( 40.1 versus $3.3 \mathrm{mg} / \mathrm{g}$ fresh liver, $P<0.01$ ) but did not modify the hepatic concentrations of the other lipid classes. TG of chylomicrons and of very low density lipoproteins (VLDL) in calves fed the CO diet were rich in C12:0 (36.2 and $28.9 \%$ of total fatty acids) and, to a lesser extent, in C14:0 (16.8 and $20.1 \%$ ) and $\mathrm{C} 16: 0$ (15.2 and 19.0\%). In contrast, liver TG weakly incorporated C12:0 (10.4\%) for the benefit of C14:0 (38.1\%) and C16:0 (29.0\%). These results are probably explained by the preferential elongation of $\mathrm{C} 12: 0$ into higher saturated fatty acids. TG infiltration of the liver in the $\mathrm{CO}$ diet is not explained by a possible alteration of VLDL and high density lipoprotein secretion by the liver since the hepatic levels ( $\mathrm{AU} / 10^{3}$ cells) of their major apolipoproteins were not significantly modified by the source of dietary lipids (CO versus T) (apo B100: 15.4 versus 10.0; apo A-I:58.7 versus 42.3) as in the case of albumin (46.4 versus 49.7 ) which is known to be expressed constitutively.
Oleate oxidation by liver slices taken from preruminant calves fed a milk replacer containing beef tallow or coconut oil. B. Graulet, D. Gruffat, D. Durand, D. Bauchart (Inra-LCMH, 63122 St-Genès-Champanelle, France).

The preruminant calf is usually given a milk replacer rich in lipids $(22.4 \%$ of diet DM). A coconut oil (CO) based diet (rich in medium-chain fatty acids) favoured muscle proteinogenesis but induced a triglyceride (TG) accumulation $(\times 12)$ in the calf liver. Modifications of the fatty acid partition between esterification and oxidation in hepatocytes could explain this lipid storage. Two groups of five 2 -weekold calves were fed for 19 days a milk diet containing beef tallow $(\mathrm{T})$ or CO. Liver slices obtained from biopsies were incubated for $24 \mathrm{~h}\left(37^{\circ} \mathrm{C}, 95 \% \mathrm{O}_{2}-5 \% \mathrm{CO}_{2}\right.$ water saturated atmosphere) in a medium containing $\left[{ }^{14} \mathrm{C}\right]$-oleate. $\left[{ }^{14} \mathrm{C}\right]-\mathrm{CO}_{2}$, generated by the slices and released in the atmosphere, was trapped in hyamine hydroxyde. $\left[{ }^{14} \mathrm{C}\right]$-acid soluble products (mainly ketone bodies) were purified following the method of Williamson (1973). Results were analysed according to the multivariate repeated measure analysis.

Oleate uptake by hepatocytes was similar between liver slices of the $\mathrm{CO}$ and $\mathrm{T}$ groups (111.4 \pm 10.4 versus $91.3 \pm 9.6$ $\mathrm{nmol}$ per $\mathrm{g}$ fresh liver and per $\mathrm{h}$, respectively). Oxidation of oleate into $\mathrm{CO}_{2}$ in the $\mathrm{CO}$ group was four times lower than in the $\mathrm{T}$ group $(0.33$ versus $1.34 \mathrm{nmol} / \mathrm{g} / \mathrm{h}$, $P<0.05)$. Production of ketone bodies by slices was twice lower in the CO group than in the $\mathrm{T}$ group (9.85 versus $19.60 \mathrm{nmol} / \mathrm{g} / \mathrm{h}, P<0.05)$. Ketone bodies were the major oxidative form of oleate (95 to $97 \%$ of the total oxidated products). Therefore, the oxidation rate of oleate in liver slices was 2.5 times lower in the $\mathrm{CO}$ group than in the $\mathrm{T}$ group $(8.95$ versus $21.70 \%$ of oleate uptake, $P<0.01)$. 